\title{
Deep Drilling into a Mantle Plume Volcano: The Hawaii Scientific Drilling Project
}

\author{
by Edward M. Stolper, Donald J. DePaolo, and Donald M. Thomas
}

\section{Introduction}

Oceanic volcanoes formed by mantle plumes, such as those of Hawaii and Iceland, strongly influence our views about the deep Earth (Morgan, 1971; Sleep, 2006). These volcanoes are the principal geochemical probe into the deep mantle, a testing ground for understanding mantle convection, plate tectonics and volcanism, and an archive of information on Earth's magnetic field and lithosphere dynamics. Study of the petrology, geochemistry, and structure of oceanic volcanoes has contributed immensely to our present understanding of deep Earth processes, but virtually all of this study has been concentrated on rocks available at the surface. In favorable circumstances, surface exposures penetrate to a depth of a few hundred meters, which is a small fraction of the 10- to 15-kilometer height of Hawaiian volcanoes above the depressed seafloor (Moore, 1987; Watts, 2001).

The shield volcanoes of Hawaii are enormous in comparison to most other types of volcanoes. The average Hawaiian volcano has a volume of $30,000-50,000 \mathrm{~km}^{3}$ (DePaolo and Stolper, 1996; Robinson and Eakins, 2006). By comparison, stratovolcanoes like Mt. Shasta in California,

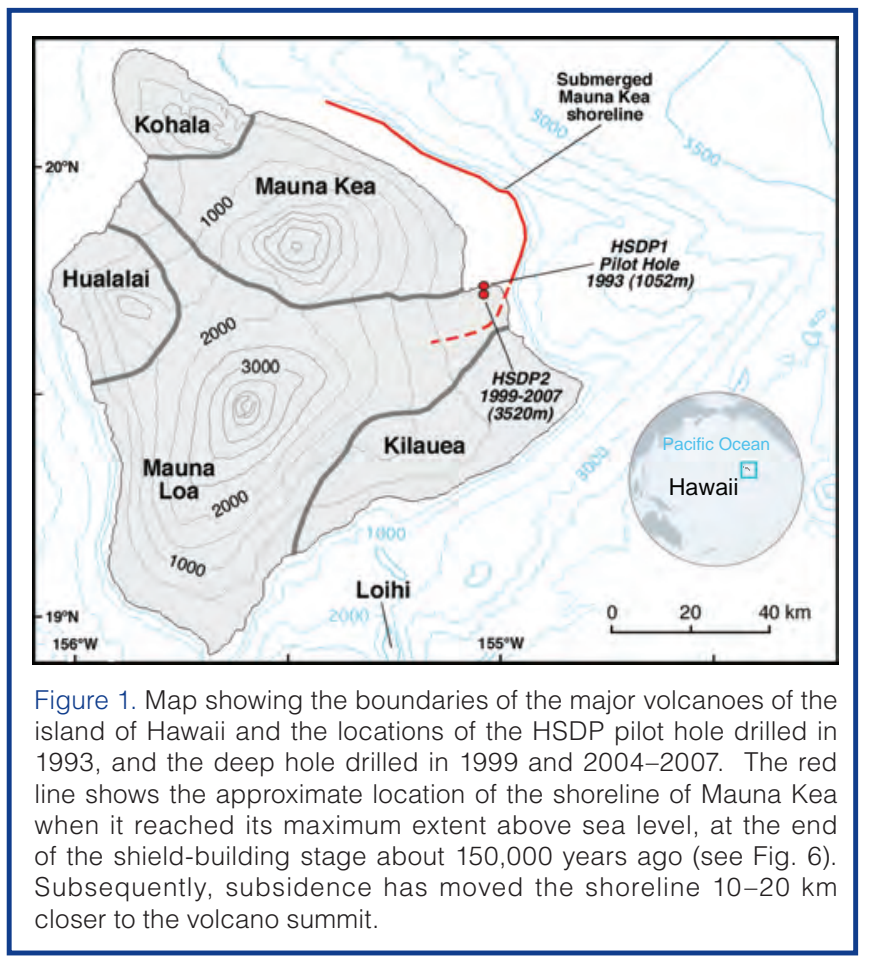

or Mt. Fuji in Japan, have volumes of only $50-500 \mathrm{~km}^{3}$. Hawaiian volcanoes grow upward from the ocean floor by systematically covering their roughly conical surfaces with new lava flows. In their main growth phase, they increase in height at an average rate of 10-30 meters per thousand years (DePaolo and Stolper, 1996), and their surfaces are completely covered with new lava about every thousand years (Holcomb, 1987). The lava flows of these large volcanoes dip gently away from the summits at angles of about 5-15 degrees relative to horizontal (Mark and Moore, 1987). The subhorizontal orientation of the flows, and the fact that they accumulate systematically with time just like sediments, means that the flanks of a volcano contain an ordered history of the volcanism that can be accessed efficiently by drilling.

The particular interest in drilling Hawaiian volcanoes is that as they grow, they are slowly carried to the northwest by the moving Pacific plate. Each individual volcano "sweeps" across the top of the Hawaiian mantle plume as it forms. The magma-producing region of the plume is roughly $100 \mathrm{~km}$ wide (Ribe and Christensen, 1999), so with the plate moving at $9-10 \mathrm{~cm} \mathrm{yr}^{-1}$, it takes a little over one million years for a volcano to cross the magma production region. During this time the volcano goes through its major growth phases, starting as a steep-sided cone on the ocean floor, growing until it breaches the sea surface and becomes a small island, and then continuing to grow, expand, and subside until it becomes a massive, 100-km-wide pancake of lava and volcanic sediment with intrusive rocks at its core. As a volcano forms, the magma supply comes first from one side of the plume, then the middle, and then the other side, so sampling a stack of Hawaiian lavas provides a cross-section through the plume. The plume itself brings up rock material that comes from the deepest layers of the mantle (Farnetani et al., 2002; Bryce et al., 2005; Sleep, 2006). Thus, by drilling a few kilometers into a Hawaiian volcano, one can in theory look $2900 \mathrm{~km}$ down into the Earth and (if current models are correct) gather information about the bottom 100 kilometers of the mantle. No other place on Earth that we know of affords the possibly of doing this with quite the regularity that is inherent to Hawaiian volcanoes.

In recognition of the opportunities afforded by drilling in Hawaiian volcanoes, the Hawaii Scientific Drilling Project (HSDP) was conceived in the mid-1980s to core continuously to a depth of several kilometers in the flank of a Hawaiian volcano. The Mauna Kea volcano, which makes up the north- 
eastern part of the island of Hawaii, was chosen as the target (Fig. 1). The drill sites are located within the city of Hilo at elevations just a few meters above sea level. The project proceeded in three phases of drilling. What we refer to as "HSDP1" involved coring a pilot hole to a depth of 1052 meters below sea level (mbsl) in 1993 (Stolper et al., 1996; DePaolo et al., 1996). The deep drilling project, referred to as HSDP2, took place in two phases. In the first phase a hole was core drilled in 1999 to a depth of $3098 \mathrm{mbsl}$ (3110 m total depth; DePaolo et al., 2001b). In the second phase the hole was cased (2003) and then deepened in 2004-2007 to a final depth of 3508 mbsl (3520 m total depth). After each phase of coring, an integrated set of investigations characterized the petrology, geochemistry, geochronology, and the magnetic and hydrological properties of the cored lavas. Most of the funding for this long-term project was provided by the National Science Foundation (U.S.A.) through its Continental Dynamics program, but critical support for drilling was received for the 1999 and 2004-2007 phases from the ICDP. We summarize here the results of the HSDP1 and HSDP2-Phase 1 drilling and preliminary results of ongoing studies from the HSDP2-Phase 2 drilling.

\section{Site Location}

An abandoned quarry on the grounds of Hilo International Airport was chosen as the site for HSDP2. The HSDP1 pilot hole was located $2 \mathrm{~km}$ to the NNW, north of the airport, within fifty meters of the shoreline of Hilo Bay (Fig. 1; Stolper et al., 1996; DePaolo et al., 1996). Although the Mauna Kea volcanic section was the primary target, the HSDP sites in Hilo required drilling through a veneer of Holocene Mauna Loa flows. The Mauna Kea lavas are encountered at depths of 280-245 m. Because the volcanoes are younger to the southeast, and overlap with subsurface boundaries sloping to the southeast (Moore, 1987), it was expected that once Mauna
Kea lavas were entered, the hole would remain in Mauna Kea to total depth. The drill sites were chosen to be (1) far from volcanic rift zones to avoid intrusive rocks, alteration, and high-temperature fluids; (2) close to the coastline to minimize the thickness of subaerial lavas that would need to be penetrated to reach the older, submarine parts of the volcano; and (3) in an industrial area to minimize environmental and community impacts.

\section{Drilling and Downhole Logging}

The main phase of HSDP2 drilling in 1999 consisted primarily of successive periods of coring to predetermined depths, followed by rotary drilling to open the hole for installation of progressively narrower casing strings (Fig. 2). No commercially available system could satisfy both the coring and rotary drilling requirements, so a hybrid coring system (HCS) was designed and fabricated. The HCS employed a rotating head and feed cylinder to drive the coring string, and it was attached to the traveling block of a standard rotary 


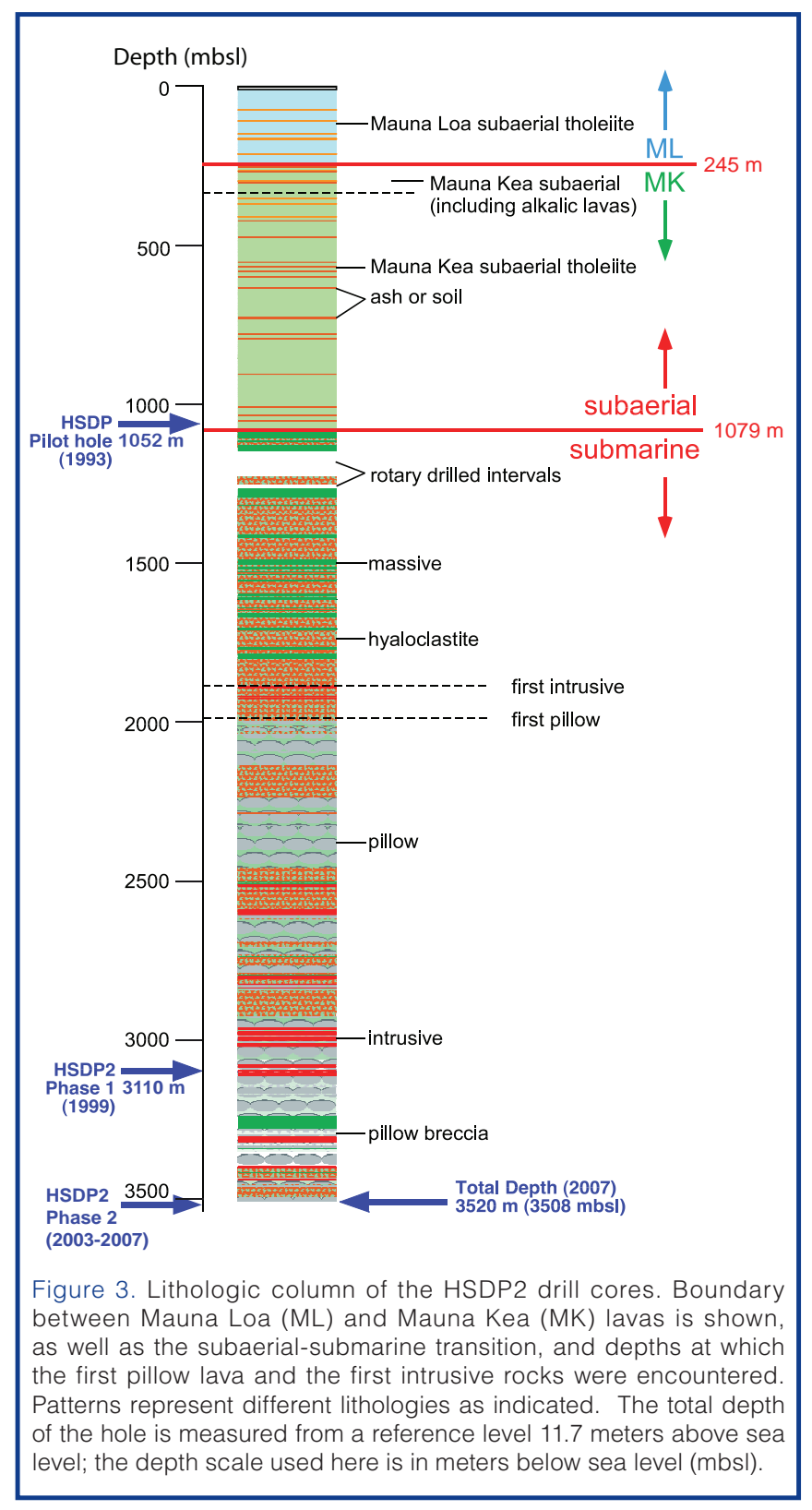

rig to allow core and rotary drilling from the same platform. Core penetration rates averaged $48 \mathrm{~m} \mathrm{~d}^{-1}$ through the subaerial section, but slowed upon entering the submarine section, where poorly consolidated hyaloclastites (Fig. 3) led to short bit life and poor core recovery. A 3.5-inch tricone bit, driven by the coring unit, was used to penetrate the most difficult portion of this interval, the only significant depth interval where core was not recovered. Progressive induration of the hyaloclastites with depth enabled an average penetration rate of $\sim 25 \mathrm{~m} \mathrm{~d}^{-1}$ down to the first occurrence of pillow basalts (1980 mbsl; Fig. 3). The opening of the hole and setting of the casing also progressed well; the rotary drilling penetration rate down to 1820 mbsl averaged $\sim 46 \mathrm{~m} \mathrm{~d}^{-1}$.

After casing was set to $1820 \mathrm{mbsl}$, coring through the alternating intervals of pillow and hyaloclastite progressed at a slower rate than in the upper section of hole. Reduced rates of penetration were expected due to the longer trip time, but two additional factors contributed. In the thinly bedded pillow lavas, the core tended to fragment as it was cut from the formation, thus blocking the core barrel and resulting in short core runs. Broken core fragments also tended to drop into the drill string as the core tube was brought to the surface. These fragments needed to be cleared from the drill string before sending a new core tube down, and this process typically added nearly an hour to the core retrieval process. Higher rates of bit wear also required more frequent trips to change the bit. In spite of these challenges, an average penetration rate of $\sim 21 \mathrm{~m} \mathrm{~d}^{-1}$ was maintained down to $2986 \mathrm{mbsl}$, where a zone was encountered in which the basalts were thoroughly broken and unstable. This broken zone triggered some deviation of the hole from vertical and presented additional problems with rubble caving into the hole and threatening to jam the bottom hole assembly (BHA). The drillers tried various strategies to deal with the caving, but they achieved only a small amount of additional progress before the decision was made to terminate coring operations at a depth of $3098 \mathrm{mbsl}$ and run downhole logs. The hole was then left filled with heavy mud.

The HSDP Phase 2 drilling commenced in March to August 2003, by first enlarging the diameter of the hole below the 7-inch casing from 3.85 -inches to 6.5 -inches , and then installing a 5 -inch casing to bottom (Fig. 2). Because the casing weight was beyond the capacity of any Hawaiibased drill rigs, a rotary rig was acquired for the project. This "hole-opening" phase proved difficult due largely to unexpected high formation fluid pressures. Before the start of hole opening, the well produced artesian water at a modest rate from depths of $2605 \mathrm{mbsl}, 2370 \mathrm{mbsl}$, and $2059 \mathrm{mbsl}$. However, soon after the hole was widened, strong water flow began. As depth increased, formation pressures increased. The peak wellhead pressure was measured at $\sim 11$ bar, and water flow rates reached as high as $250 \mathrm{~L} \mathrm{~s}^{-1}$. Initial efforts at controlling flow with increased mud weight were only partially successful, as was an alternative cementing strategy. As a result, progress for most of the hole opening was difficult, dangerous, and slow. Eventually, after the hole had been opened down to about $2732 \mathrm{mbsl}$, a decision was made to allow the hole to flow freely, with periodic mud "sweeps" conducted to ensure that cuttings were fully cleared from the hole. This strategy was successful and the penetration rate increased from $<20 \mathrm{~m} \mathrm{~d}^{-1}$ to nearly $100 \mathrm{~m} \mathrm{~d}^{-1}$. Hole opening then continued down to $2997 \mathrm{mbsl}$, where caving problems were again encountered. After several attempts at drilling through the problematic zone, each resulting in a temporarily stuck BHA, the decision was made to terminate hole opening and to begin casing.

Challenges during the hole-opening phase continued when improper lifting tools were used, and late in the process a 2347-m string of 5-inch casing was dropped into the hole. After the condition of the dropped casing was checked, it was left in the hole. The casing was completed by threading an additional 610-m string onto the top of the dropped casing; 
the bottom of the casing was at a depth of $2997 \mathrm{mbsl}$. As the follow-on coring work began in late 2004, we discovered that the bottom joint of the dropped casing string had been damaged. It was necessary, using special tools, to cut a window through the side of the bent casing to extend the hole. After rubble was cleared from the hole down to $3098 \mathrm{mbsl}$, coring proceeded in two stages (December 2004 to February 2005, and December 2006 to February 2007) to a total depth of $3508 \mathrm{mbsl}$. The first coring effort averaged only $6 \mathrm{~m} \mathrm{~d}^{-1}$ and reached $3326 \mathrm{mbsl}$. At that point the rotary rig was sold, and a leased coring rig was used. The coring done in early 2007 achieved about $8 \mathrm{~m} \mathrm{~d}^{-1}$, but problems with the leased rig and exhaustion of project funds resulted in only $180 \mathrm{~m}$ of additional core.

At the conclusion of HSDP2-Phase 2 drilling, the 5-inch casing was perforated, cement was pumped into the annulus at depth, and at $2031 \mathrm{mbsl}$, the casing was cut at $1635 \mathrm{mbsl}$ and the top section removed from the hole. The final depth of the HSDP core hole is about $914 \mathrm{~m}$ less than was originally planned in 1996, but it is still nearly twice as deep as the next deepest core hole drilled in Hawaii (SOH-2 to $2073 \mathrm{~m}$ on the Kilauea East Rift Zone; Novak and Evans, 1991).

\section{Hydrology}

Although the primary purpose of the borehole was to document the geochemical evolution of an oceanic volcano, a significant finding was the unexpected hydrology. The traditional view of ocean island subsurface hydrology is one of a freshwater lens (fed by rainfall recharge) "floating" atop saltwater-saturated rocks that extend to the island's base. Circulation of seawater within the basement rocks is presumed to occur to the extent made possible by permeability and thermal conditions. The HSDP boreholes showed that the hydrology of the island of Hawaii is considerably more complicated and interesting. Whereas it has been assumed that the youth of the island of Hawaii meant that artesian aquifers, such as those arising from the buried cap rocks on Oahu, would be absent, the borehole encountered multiple artesian aquifers (Fig. 2). Estimated groundwater flow through the first of these, at a depth of only $300 \mathrm{~m}$, may represent as much as a third of the rainfall recharge to the windward mid-level slopes of Mauna Kea. The deeper artesian aquifers have equally unexpected implications. Some of the groundwater produced by the deep aquifers was hypersaline, with chloride concentrations about $20 \%$ higher than seawater. These aquifers must be isolated from ocean water, and they may have lost $25 \%$ of their water to hydration reactions with basalt glass. Other fluids produced by the borehole had salinities less than half those of seawater, indicating that a connection exists between these deep confined pillow aquifers and the basal fresh groundwater system. Evidence for freshwater in the formation fluids was found in the borehole to as deep as $3000 \mathrm{mbsl}$, implying that the volume of freshwater within Mauna Kea may be ten times greater than previously estimated.

\section{Thermal Profile}

The downhole temperature profile for the HSDP2 corehole (Fig. 2) yields additional information about the subsurface hydrology of Hawaii. Within the first $200 \mathrm{~m}$ of the borehole, the thermal conditions were consistent with the expected basal freshwater lens underlain by rocks saturated with freely circulating saline water. However, at $\sim 300 \mathrm{~m}$ a temperature reversal occurs that was later demonstrated to be the result of a $\sim 150$-m-thick freshwater aquifer confined by multiple soil and ash layers present at the interface between Mauna Loa lavas and late-stage Mauna Kea flows (Thomas et al., 1996). Below the artesian fresh aquifer, the temperature falls rapidly to $\sim 9^{\circ} \mathrm{C}$, reflecting the presence of an actively circulating saltwater system that draws deep, cold sea water in through the submerged slopes of Mauna Kea. Circulation within this system is rapid enough to maintain a very weak temperature gradient $\left(\sim 7^{\circ} \mathrm{C} \mathrm{km}^{-1}\right)$ down to a depth of $\sim 1600 \mathrm{mbsl}$ where the gradient begins a progressive rise to $\sim 19^{\circ} \mathrm{C} \mathrm{km}^{-1}$ at $2000 \mathrm{mbsl}$. This value is to be expected for a conductive thermal gradient (Büttner and Huenges, 2002). Temperature measurements made below 2000 mbsl under static conditions (no internal well flow) show a nearly constant $19^{\circ} \mathrm{C} \mathrm{km}^{-1}$ gradient to total depth. Downhole temperature measurements made during and soon after well flow show sharper temperature gradients that are interpreted to reflect flow into or out of the formation during drilling or production, respectively. The positive temperature steps at permeable formations indicate entry of warm fluids from deep within Mauna Kea's core.

\section{Lithologic Column}

A major effort was made to characterize and catalogue the rock core on-site. This nearly-real-time logging allowed us to monitor the volcano structure, which helped with drilling and allowed us to immediately start systematic sampling. On-site activities included hand-specimen petrographic description and photographic documentation of the recovered core. There were 389 distinguishable lithological units identified (e.g., separate flow units, sediments, soils). A simplified version of the lithological column is shown in Fig. 3. A diagrammatic representation of the internal structure of the Mauna Kea volcano in the vicinity of the drill site (Fig. 4) helps explain the significance of the volcanic stratigraphy.

The core was split longitudinally into a working portion (two-thirds) to be used for analysis and an archival portion (one-third) to be reserved for future study. A reference suite of samples for geochemical analyses, chosen to be representative and to cover the depth of the core at specified intervals, was taken on-site and sent to participating scientists. A key feature of the sampling is that a complete suite of petrological and geochemical analyses was conducted on these reference samples, allowing for a high level of comparability among complementary textural, chemical, 
and isotopic measurements. All of the data collected on-site can be accessed at http://www.icdp-online.org/contenido/ icdp/front_content.php?idcat=714,; the data include digital photographs of each box containing the working and archival splits, high-resolution scans of the working split, a detailed lithological column, and detailed descriptions of the entire recovered core. A summary of the lithologic column from the HSDP2 drilling follows.

Subaerial Mauna Loa lavas (surface to $246 \mathrm{mbsl}$ ): The lava flows from the surface to $246 \mathrm{mbsl}$ are all subaerial Mauna Loa (ML) tholeiites, as determined by major and trace element analyses. These flows range from aphyric to 30\% (by volume) olivine phenocrysts; the average phenocryst abundance is $\sim 11 \%$. Thirty-two flow units with an average thickness of $\sim 8 \mathrm{~m}$ were identified in this depth range; and pahoehoe flows are approximately equally abundant. A total thickness of 2-3 m of ash, soil, and volcanic sandstone occurs

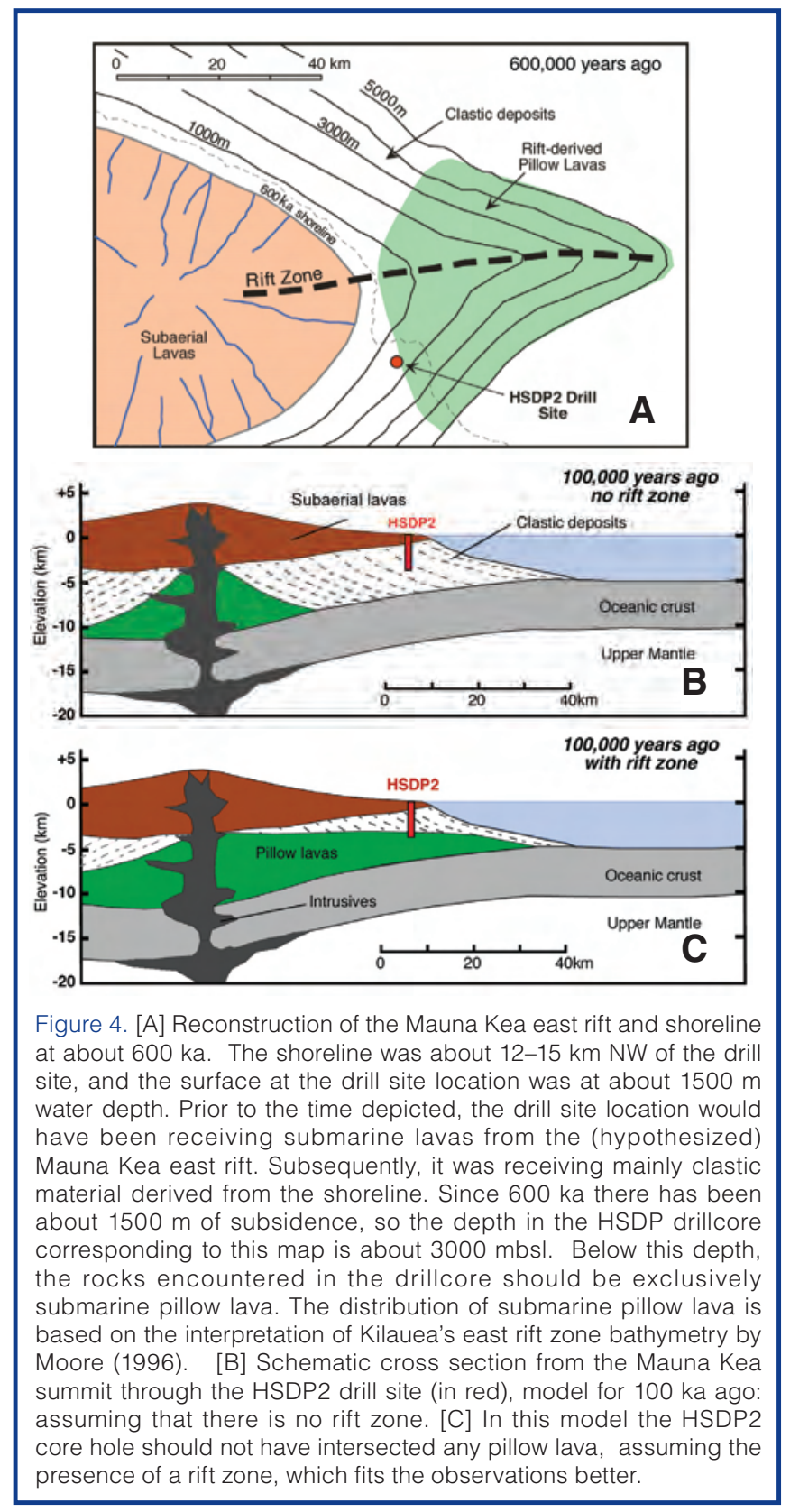

interspersed with the ML lavas. The contact between the ML lavas and underlying subaerial Mauna Kea (MK) lavas occurs at $246 \mathrm{mbsl}$. Lavas from the two volcanoes are sufficiently different in chemical and isotopic compositions that it is easy to demonstrate that there is no interfingering of lavas from the two volcanoes, which is consistent with subsurface structural analysis based on the age and growthrate relations between Mauna Kea and Mauna Loa (DePaolo and Stolper, 1996). Although the drill site was near that of the pilot hole, and the depths of the ML-MK transition (275 mbsl in the pilot hole) are similar at the two sites, the shallow carbonates and beach deposits observed in the pilot hole (DePaolo et al., 1996) are not present in the HSDP2 core.

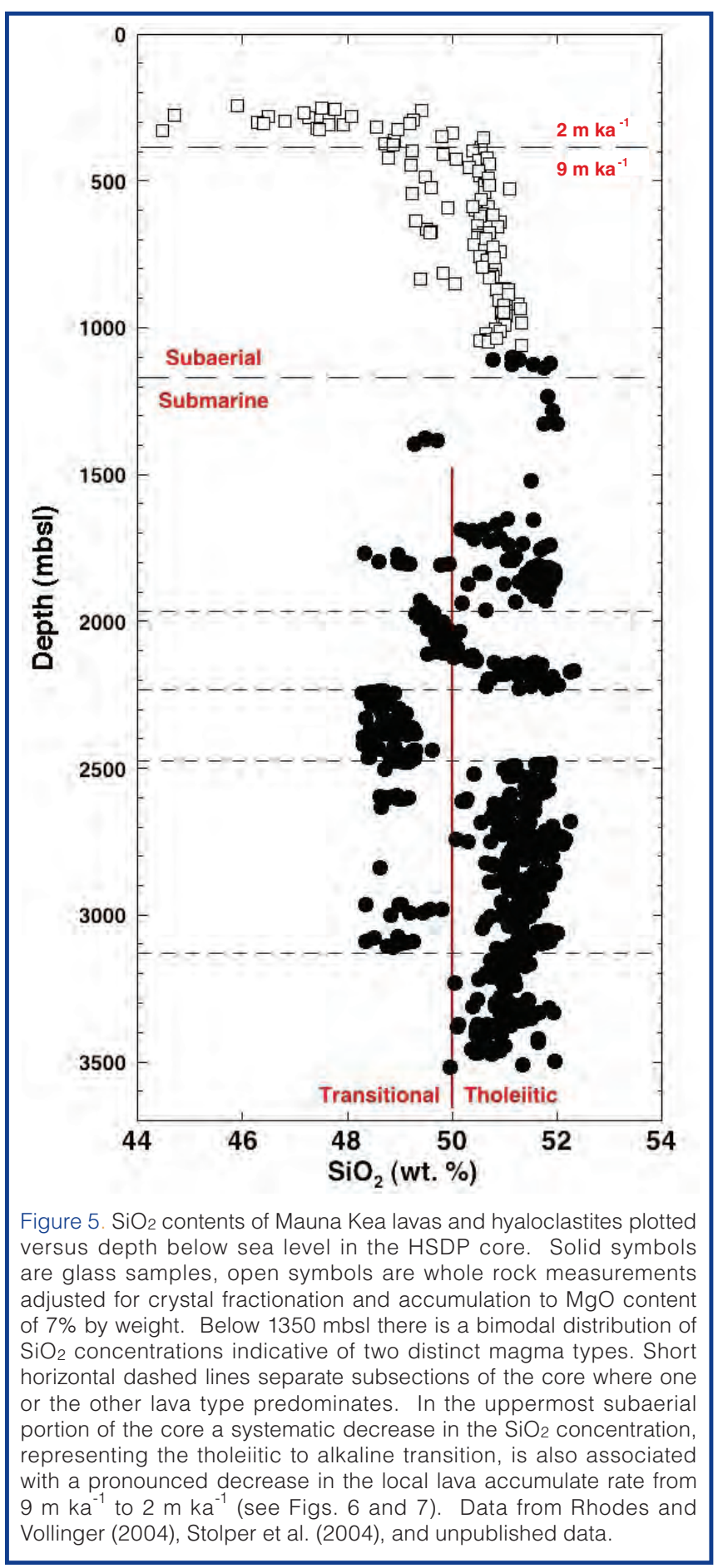


Moreover, although the number of ML flow units identified in the HSDP2 core is similar to that in the pilot hole (thirty), there is no one-to-one correspondence of units in the two cores below the first few near-surface flows. Dating of the ML section of the pilot hole core suggests that it extends back to about $100 \mathrm{ka}$ (Lipman and Moore, 1996). During this time trace element and isotopic geochemistry show significant changes; most of the samples from the core are quite different from sub-aerially exposed lavas of Mauna Loa (DePaolo et al., 2001a).

Subaerial Mauna Kea lavas (246-1079 mbsl): The upper $834 \mathrm{~m}$ of the MK section comprises primarily $\sim 120$ subaerial flows of $7 \mathrm{~m}$ average thickness; about twenty-five percent of these flows are pahoehoe. A total thickness of $\sim 2 \mathrm{~m}$ of ash and soil occurs within and between many flow units. Chemical analyses (Fig. 5) demonstrate that the uppermost $~ 50 \mathrm{~m}$ of the MK section contains interbedded nepheline-normative (low $\mathrm{SiO}_{2}$ ) and hypersthene-normative lavas, marking the end of the shield-building phase of MK's volcanic cycle (Rhodes and Vollinger, 2004). Deeper subaerial MK lavas are tholeiitic with variable olivine phenoscryst content (0-35 volume \%).

Submarine Mauna Kea - dominantly hyaloclastite debris flows (1079-1984 mbsl): An abrupt transition to the submarine part of the MK section occurs at a depth of 1079 mbsl, marked by the occurrence of volcaniclastic sediments and glassy lavas significantly denser than those above the transition. Based on radiometric ages of the lavas at the base of the nearby pilot hole, the estimated age of the subaerial-submarine transition is $\sim 400 \mathrm{ka}$ (Sharp and Renne, 2004; Sharp et al., 1996; Fig. 6). The estimated average subsidence rate at the drill site over this interval, $\sim 2.5 \mathrm{~mm} \mathrm{y}^{-1}$ (corrected for sea level variations), is similar to the current subsidence rate in Hilo measured by tide gauges; to the average subsidence rate for the past several tens of thousands of years based on sediments in the pilot hole (Beeson et al., 1996); and to the average values over 100-200 ka at several near-shore sites around Hawaii based on the ages of drowned coral reefs (Moore et al., 1996).

The upper $60 \mathrm{~m}$ of the submarine section (1079-1140 mbsl) is different from the rest of the submarine section. This nearshore facies is an alternation of massive basalts $(2-3 \mathrm{~m}$ average thickness) and clastic sediments ( $\sim 3 \mathrm{~m}$ average thickness; dominantly basaltic hyaloclastite). These occur in roughly equal amounts. The vesicularity of the massive basalts in this depth range is variable but mostly lower than the $10 \%-20 \%$ typical of the subaerial lavas; when combined with the low water and sulfur contents of most glasses from these basalts, this suggests that these massive basalts are subaerialflows that continued past the shoreline as submarine flows. The hyaloclastites consist of a matrix rich in glassy fragments plus basaltic lithic clasts from $<1 \mathrm{~cm}$ up to several tens of centimeters in size. These clasts are similar lithologically to the massive basaltic units, although they are usually more vesicular. The basalts in this depth range are highly fractured, and the hyaloclastites are poorly indurated, leading to the poor drilling conditions described above.

The interval from $1220 \mathrm{mbsl}$ to $1984 \mathrm{mbsl}$ consists of $~ 90 \%$ well-indurated basaltic hyaloclastite, interspersed with $10 \%$ massive submarine basalts (Fig. 3). The basalts are divided into twenty-six units with an average thickness of 3-4 m. They are olivine phyric, and point counts and chemical analyses indicate a systematic decrease in olivine abundance with depth in this interval from $>20 \%$ at the top to $<10 \%$ at the bottom. The vesicularity of the massive basalts in this interval is typically $<1 \%$. Although some of these massive basalts could be intrusives or large lithic clasts, most have been interpreted as subaerial flows that continued past the shoreline as submarine flows. As at the top of the submarine section, the hyaloclastites in this deeper interval comprise a matrix often rich in fresh glass fragments plus variably olivine-phyric, variably vesicular basaltic lithic clasts. In some intervals, where these volcaniclastic sediments are bedded and/or poor in lithic clasts, they are described as sandstones or siltstones. Analyses of water and sulfur contents of glassy fragments in the hyaloclastites demonstrate that they have been degassed subaerially. This composition, plus the often highly vesicular nature of the basaltic clasts and the presence of charcoal in at least one hyaloclastite, suggests that this thick interval of hyaloclastite represents material transported downslope (probably by slumping from oversteepened near-shore environments) as the shoreline moved outward during the subaerial phase of growth of the Mauna Kea volcano (Moore and Chadwick, 1995; Fig. 4).

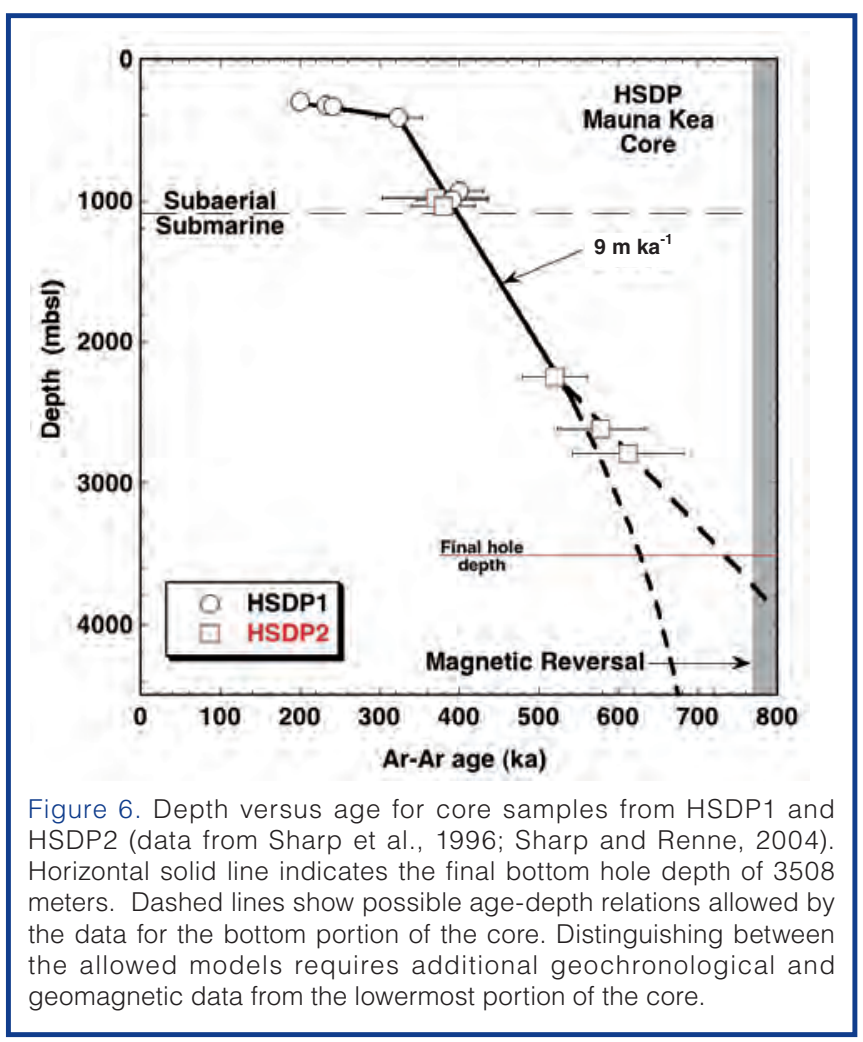


Submarine Mauna Kea - dominantly pillow lavas (1984-3098 mbsl): From a depth of $1984 \mathrm{mbsl}$ to the to the depth reached in the 1999 phase of drilling, the section is $\sim 60 \%$ pillow basalt, with less abundant intercalated volcaniclastic sediment (Fig. 3). Several thick intervals (up to $\sim 100 \mathrm{~m}$ each) composed nearly entirely of sediment are also present. The sediments are primarily hyaloclastite, and they were probably transported from near-shore environments. The pillows typically have fresh glassy margins; the average olivine content is $\sim 6 \%$ by volume, much lower than the average for the subaerial MK flows. Vesicularities range up to $10 \%$, but the average is $1 \%-2 \%$. Water contents of the glassy pillow margins are $\sim 0.08 \mathrm{wt} \%$ at $1984-2140$ mbsl (consistent with subaerial degassing), but most pillow margins from depths $>2200 \mathrm{mbsl}$ have water contents of $0.2-0.8 \mathrm{wt} \%$. The waterrich, deeper lavas were never degassed under subaerial conditions and are interpreted as submarine eruptions. The deepest $\sim 180 \mathrm{~m}$ of this interval contains no hyaloclastite. Before drilling the final $422 \mathrm{~m}$ (see below) it was hypothesized, based on the presence of the 180-meter hyaloclastite-free section, that pillow lavas would dominate the deeper sections of the core.

Submarine Mauna Kea - the final phase of drilling (3098-3508 $\mathrm{mbsl}$ ): Although the final phase of drilling was at times challenging as described above, core recovery was close to $100 \%$. All rocks from the final phase of drilling were deposited below sea level; based on chemical analyses currently available of whole rocks and glass, they have been determined to be from the Mauna Kea volcano, On-site core logging led to the identification of forty-four distinguishable units (the main phase of drilling had identified 345 units). Five lithologies were identified: pillows ( 60\%); pillow breccias $(\sim 10 \%)$; massive lavas $(\sim 12 \%)$; hyaloclastites $(\sim 17 \%)$; intrusives $(\sim 1 \%$; these are mostly multiple, thin (down to cm-scale) fingers of magma with identical lithologies occurring over narrow depth intervals; see next section). As with the shallower portions of the drill core, the rocks are primarily tholeiitic, ranging from aphyric to highly olivinephyric lavas (up to $\sim 25 \%$ olivine phenocrysts). Although they are variably altered (clays, zeolites), considerable fresh glass and olivine are present throughout this part of the core. Forty whole-rock samples were collected as a reference suite, processed (including the cutting of thin sections), and sent to multiple investigators for study. Additionally, glass was collected at roughly 3-m intervals for electron microprobe analysis.

Although samples were continuous and consistent with the shallower rocks from the previous phases of coring, there are several noteworthy features of the deepest $422 \mathrm{~m}$ of core. (1) Glasses from the shallower core were characterized by bimodal silica contents (Fig. 5, a low $\mathrm{SiO}_{2}$ group (48-49 wt \%), and a high $\mathrm{SiO}_{2}$ group (51-52 wt \%). Glasses from the deepest section are essentially all in the high $\mathrm{SiO}_{2}$ group and are somewhat more evolved (5.1-7.6 wt \% MgO compared to $5.1-10.8 \mathrm{wt} \%$ for the glasses from the shallower portion of the core). (2) The overall expected sequence of lithologies with depth in the core is subaerial lava flows, hyaloclastite (formed by debris flows carrying glass and lithic fragments from the shoreline down the submarine flanks of the volcano), and finally pillow lava (Fig. 4). This sequence was generally observed in the earlier phases of drilling, and it appeared that the deepest rocks from the 1999 phase of drilling were essentially all formed from pillow lavas (i.e., there were no more hyaloclastites). However, thick hyaloclastites reflecting long distance transport from the ancient shoreline reappear in the bottom $\sim 100 \mathrm{~m}$ of the drill hole. Although it may be coincidence, pillow breccias occur in the shallower parts of the core from the final phase of drilling, but not in the deeper parts in which the hyaloclastites reappear. (3) There are three units classified as "massive" including one relatively thick $(\sim 40 \mathrm{~m})$, featureless (no internal boundaries, no evidence of mixing or internal differentiation) moderately olivine-phyric basalt. Their origin is unclear.

Intrusive units: Intrusive basalts are present in the deepest portions of the core, but they are abundant nowhere; between their first occurrence at $1880 \mathrm{mbsl}$ and the bottom of the core, they make up several percent of the core. They are most abundant in the 2500-3100 mbsl interval, where they constitute $7 \%$ of the core (Fig. 3). Intrusive rocks make up a lower fraction $(\sim 1 \%)$ of samples from the final phase of coring than in the deeper parts of the section from the 1999 phase of drilling. It had been suggested that intrusives might become more common the deeper the drilling, but this is not the case at depths down to $3500 \mathrm{~m}$. Individual intrusive units typically occur as multiple, thin (up to a few centimeters long) splays or fingers. The average olivine phenocryst content is $4 \%-5 \%$, and their vesicularities are all $\leq 1 \%$. The relationship of the intrusives to the lavas and sediments they intrude is not firmly established, but the lobate shapes of some of the intrusive contacts with the hyaloclastites suggest that the latter were still soft when they were intruded.

Alteration and faulting: Basalts in the subaerial and submarine parts of the section are relatively fresh (unweathered), based on the presence of fresh glass and olivine. Although secondary minerals (e.g., gypsum, zeolites, clays) are common below $1000 \mathrm{mbsl}$, they tend to be localized in vesicles or lining fractures (Walton and Shiffman, 2003; Walton, 2008). Olivines are often partially altered, and in some of the subaerial lavas the matrix is clayey. The overall fresh nature of the rocks is consistent with their low vesicularity and the low downhole temperatures (Fig. 2). The hydrology of the drill site may also contribute to this, in that less reactive, freshwater is present to great depth. Near the base of the core, there is some suggestion of an increased abundance of secondary minerals and alteration based on hand-specimen descriptions. An interesting aspect of the alteration is a blue coating on most fragments starting near the depth of the subaerial-submarine transition that becomes less apparent after several hundred meters. Another distinctive feature is a bright blue-green alteration zone extending 
up to $\sim 30 \mathrm{~cm}$ into hyaloclastites from intrusive contacts; although striking when the core came out of the ground, it faded and was difficult to distinguish within a few weeks. No significant fault displacements were observed in the core, but slickensides (though rare) are found throughout the section, demonstrating that at least local relative motions occurred in the section.

\section{Key Petrologic, Geochemical, and Volcanological Results}

Although only preliminary results are available for the final phase of drilling, considerable work has been completed on the samples recovered in the two previous phases of drilling. We summarize them briefly here, with references to the primary publications.

Age and growth rates of Hawaiian volcanoes: Much of what we can infer from the studies of the chemical and isotopic composition of the lavas depends on their age. What we have learned about the age of lavas is summarized in Fig. 6. The deepest dated sample (at $2789 \mathrm{mbsl}$ ) has an age of $683 \pm 82 \mathrm{ka}$ (Sharp and Renne, 2004). Comparison with previous age and growth rate estimates for the Hawaiian volcanoes (Moore and Clague, 1992) indicates that the volcano lifetimes are apparently almost four times longer than was inferred from surface data (although very close to our predictions as laid out in the 1991 NSF proposal). Reconciling the age data from the core with the surface observations is a challenge still to be undertaken, but one of the implications is that we have been able to sample a long time period and hence have a long record of the magma output from the Hawaiian plume. Figures $4 \mathrm{a}$ and 7 show the island geography roughly 600,000

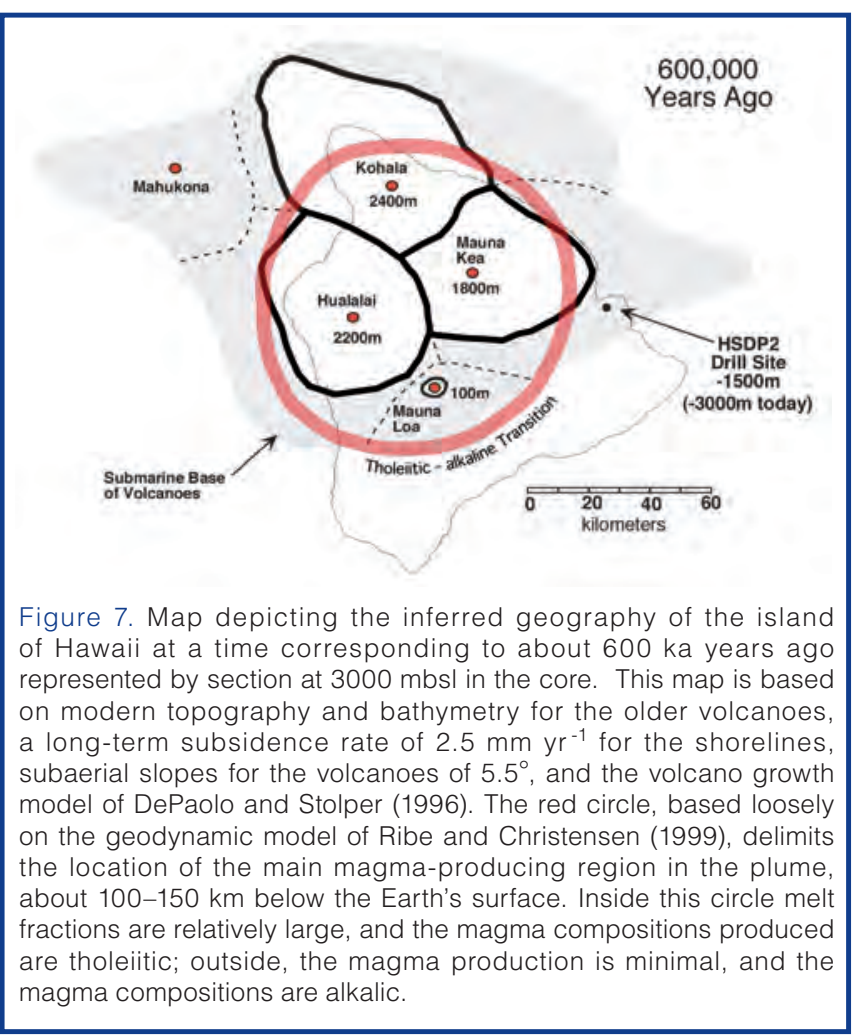

years ago as reconstructed from the HSDP age data and the models of DePaolo and Stolper (1996). To date, we have had difficulty in reconciling the growth history of the volcanoes with what is known of the Pacific plate velocity over the plume, both its speed and direction (DePaolo et al., 2001a). Based on the ages of the older islands and seamounts in the Hawaiian chain, the long-term inferred velocity of the plate is about $8.6 \mathrm{~cm} \mathrm{yr}^{-1}$. Modern GPS measurements suggest a present-day plate velocity of $7 \mathrm{~cm} \mathrm{yr}^{-1}$. Moore and Clague (1992), on the basis of their growth model, suggested that the volcanoes on the island of Hawaii were moving over the plume at a velocity of $13 \mathrm{~cm} \mathrm{yr}^{-1}$ or more! So far, we have been able to make a reasonable fit to the age data with a velocity of $10 \mathrm{~cm} \mathrm{yr}^{-1}$, but this model can probably only be tested by drilling in other volcanoes.

Lava stratigraphy and volcano evolution: Excluding the abrupt change from the Mauna Loa lavas at the top of the core to the Mauna Kea lavas that extend over most of the length of the core, there is considerable evidence of chemical and isotopic heterogeneity in the recovered lavas (Figs. 5 and 8). The data provide critical insights into plume structure and the time dependence of magma generation over much of the lifetime of the Mauna Kea volcano. Two key results are described here. (1) The coring captured in detail the termination of the shield-building phase of the Mauna Kea volcano at about $150-300 \mathrm{ka}$, which is characterized by a shift from tholeiitic to alkaline magmas and a drastic slowing of eruption rate (Figs. 5 and 6). These changes reflect a shift in degree and depth of melting as the volcano passed from the center to the exterior of the melt-producing region of the mantle plume (Fig. 7). (2) The Mauna Kea section is characterized by a bimodal distribution of $\mathrm{SiO}_{2}$ contents in the lavas of the main, shield-building phase of the volcano, with both abrupt and continuous transitions between the two magma types occurring in the section (Fig. 5). The bimodal compositional distribution has never previously been observed in Hawaii, and since these major element characteristics are correlated with isotopic ratios, they indicate a bimodal distribution of source components. In a potentially major paradigm shift, these results may suggest that the mantle source materials in the Hawaiian plume are not peridotite (i.e., olivine-rich) as generally thought, but rather pyroxene-rich lithologies that straddle a thermal divide.

Geochemical structure of the Hawaiian mantle plume: The HSDP geochemical data can be interpreted in terms of the geochemical structure of the Hawaiian plume. The continuous nature of the HSDP core, with the implied continuous monitoring of the lava output from the volcanoes, has dictated that we develop models for the plume behavior just below the lithosphere and for how magma is collected from the plume melting region and supplied to an individual volcano. These models can be constrained by the volume and volume-age structure of the Hawaiian volcanoes and by available geodynamic models for the Hawaiian plume (DePaolo and 
Stolper, 1996; DePaolo et al., 1996; Ribe and Christensen, 1999; DePaolo et al., 2001a; Bryce et al., 2005). Systematic variability in Hawaiian lavas with depth (age) in the drillcore can be attributed to structure in the plume, and one of the interesting results is that there is such structure even though melting within the plume represents only the innermost third or so of the plume radius (Fig. 8). The data show that there is radial geochemical zoning of the melting region of the plume in terms of $\mathrm{He}, \mathrm{Pb}, \mathrm{Nd}, \mathrm{Sr}$ and $\mathrm{Hf}$ isotopes (Blichert-Toft et al., 2003; Eisele et al., 2003; Kurz et al., 2004; Bryce et al., 2005). This geochemical structure represents the hot core of the plume and does not reflect entrainment of ambient lower or upper mantle. The radial component of the geochemical structure of the plume represents the vertical structure at the thermal boundary layer from which the plume originates (Fig. 9). In the case of Hawaii, all of the
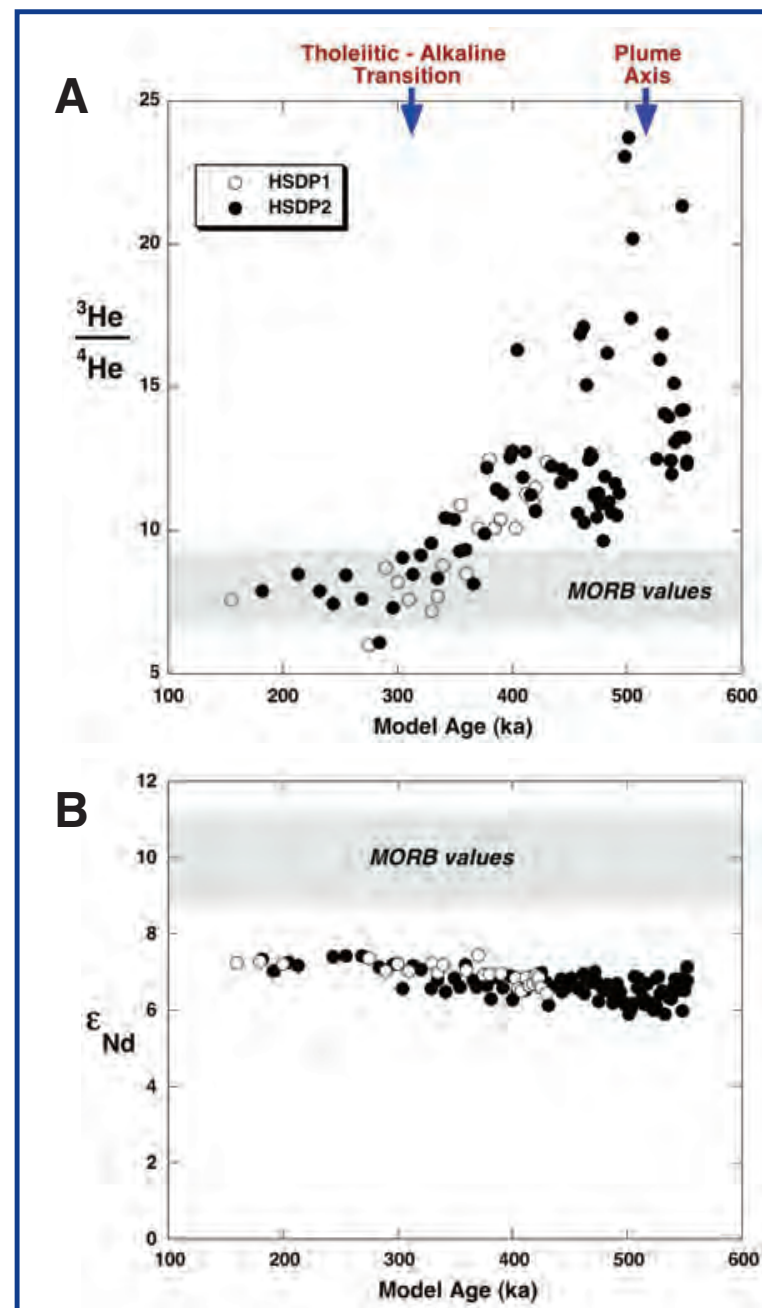

Figure 8. Isotopic composition of $[\mathrm{A}] \mathrm{He}$ and [B] Nd in HSDP lavas plotted versus age. The ages were assigned using the model of DePaolo and Stolper (1996) and are consistent with the measured ages (Fig. 6). During the period of time represented by the core samples (ca. $600 \mathrm{ka}$ to $150 \mathrm{ka}$ ), the summit of the Mauna Kea volcano moved from a position close to the center of the plume melting region (depicted in Fig. 7) to a position close to the edge of the melting region. The systematic shift of isotopic ratios shows that there is radial structure within the plume. The isotopic variations are more dramatic; near the center of the plume they are much different from mid-ocean ridge basalt (MORB) values and indistinguishable from them at the edge of the melting region (data from Kurz et al., 1996, 2003). The Nd isotopic variations are subtle but consistently different from MORB values (data from Bryce et al., 2005). lavas are derived from melting of mantle that originates from within $20-50 \mathrm{~km}$ of the base of the mantle (Farnetani et al., 2002). One of the most striking characteristics of the HSDP data is that a high ${ }^{3} \mathrm{He} /{ }^{4} \mathrm{He}$ anomaly $(\mathrm{R} / \mathrm{Ra}>16)$ is nested within the core of the melting region of the plume and is much larger in amplitude and much smaller in diameter than the $\mathrm{Nd}$, Sr and $\mathrm{Hf}$ anomalies (Fig. 8). A ${ }^{3} \mathrm{He}$ anomaly apparently has a different origin than the other anomalies and is restricted to the lowermost $10-20 \mathrm{~km}$ of the mantle plume source. The helium signal is therefore likely to come either directly from the Earth's core via leakage across the core-mantle boundary, or from a dense layer separating the main mantle from the outer core (Bryce et al., 2005).

Thermal history, hydrology, lithification, and alteration geochemistry: As noted above, one of the unexpected features of the HSDP drill site is the low temperature at depth (Fig. 2). The temperature profile requires that cold seawater (or deeply penetrating basal groundwater) be circulating through the volcanic pile even at depth greater than $3 \mathrm{~km}$. Moreover, as emphasized above, there are pressurized aquifers near the bottom of the hole.

Studies of alteration minerals in the hyaloclastites have so far indicated that the mineral phases represent low temperatures of alteration less than $50^{\circ} \mathrm{C}$, which is consistent with

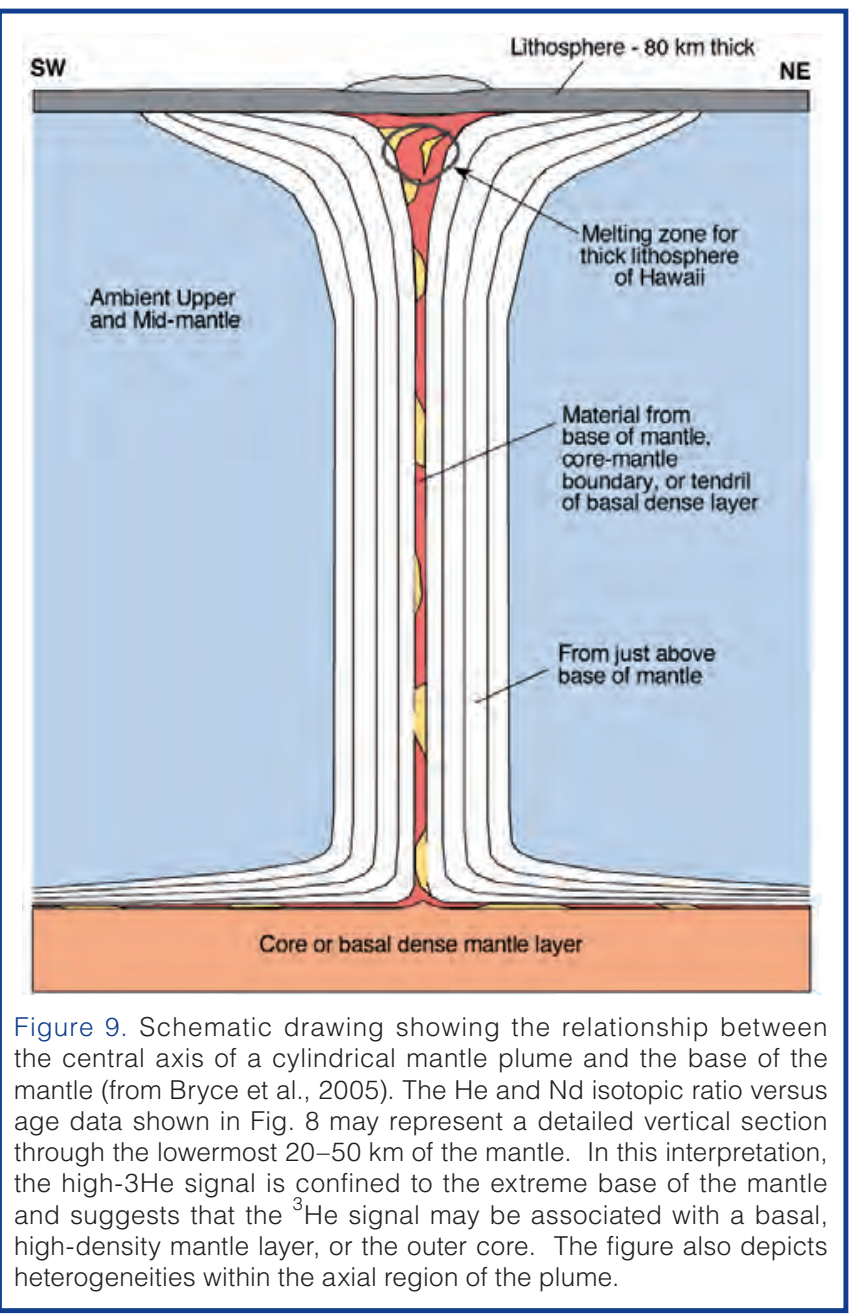


the measured temperature profile (Walton and Shiffman, 2003). Hence the temperatures in this section have always been low. The alteration mineralogy of glass in pillow rinds and pillow breccias is similar to that of hyaloclastites. A unique aspect of studying alteration of the HSDP core is that the age and stratigraphic position of the samples are known, and the temperature measurements can be used to reconstruct the thermal history. By systematically sampling down the core it is possible to reconstruct the time and temperature of both the alteration of the rocks and the microbial activity (Walton, 2008). Most other situations require study of samples with unknown temperature history or do not preserve the stages of progressive alteration and infection that can be observed in the HSDP core. The alteration process may be significant in understanding the reactions and compositional exchange between seawater and basalt glass at low temperatures, thereby providing an analogue system for the early history of fluids that circulate through mid-ocean hydrothermal systems. Signs of microbial involvement in the alteration process are evident as filamentous channels in glass, but only within a restricted portion of the core between about $1080 \mathrm{mbsl}$ and $1460 \mathrm{mbsl}$ (Walton and Schiffman, 2003; Walton, 2008; Fisk et al., 2003). This re-striction suggests that microbes infected the hyaloclastites early in their history but are not very active at present.

\section{Summary}

The Hawaii Scientific Drilling Project drilled and cored two holes in Hilo, Hawaii, the deeper reaching a depth of $3508 \mathrm{mbsl}$, and it retrieved a total of 4600 meters of rock core (525 meters from the Mauna Loa volcano and the remainder from the Mauna Kea volcano). The Mauna Loa core extends the continuous lava stratigraphy of that volcano back to $100 \mathrm{ka}$ and reveals major changes in lava geochemistry over that time period. The Mauna Kea core spans an age range from about $200 \mathrm{ka}$ to perhaps $700 \mathrm{ka}$, and when combined with surface outcrops, it provides a 700-kyr record of the lava output from a single volcano. During the time covered by the lavas from the core, the volcano drifted some $60-80 \mathrm{~km}$ across the melting region of the Hawaiian mantle plume, and therefore the HSDP rock core provides the first systematic cross-sectional sampling of a deep mantle plume. The geochemical characterization of the core, which involved an international team of forty scientists over a period of fifteen years provides information about mantle plume structure and ultimately about the deepest parts of the Earth's mantle. The study of the lava core (which still continues) has provided unprecedented information about the internal structure of a large oceanic volcano and the time scale over which volcanoes grow. The hole also provides an intriguing glimpse of a complex subsurface hydrological regime that differs greatly from the generalized view of ocean island hydrology.

Drilling conditions were favorable in the subaerial parts of the volcanic section, where coring was generally fast and efficient. The submarine part of the lava section, made up primarily of volcanogenic sediments and pillow lavas, proved considerably more difficult to drill. Some of the difficulties and considerable additional expense were due to pressurized aquifers at depth and a few critical mistakes made while setting casing. Even with the more difficult conditions, the project retrieved about 2400 meters of nearly continuous core from the submarine section of Mauna Kea. Overall, the HSDP project was highly successful even though the original target depth was about $20 \%$ deeper than the final hole depth. As expected, the project results answer several important questions about oceanic volcanoes, mantle plumes, and ocean island water resources, but they raise many more that might be addressed with further moderate-depth drilling in other Hawaiian volcanoes.

\section{Acknowledgements}

The project and the U.S. investigators were funded by the Continental Dynamics Program of the U.S. National Science Foundation (EAR-9528594 to E.M. Stolper, EAR-9528544 to D.J. DePaolo, and EAR-9528534 to D.M. Thomas), with additional funds for core drilling provided by the International Continental Scientific Drilling Program (ICDP). Non-U.S. investigators participated with support from their respective institutions and national funding agencies. The authors would like to acknowledge the critical role played by Mike Garcia in supervising the core logging and other on-site core characterization activities.

\section{References}

Beeson, M.H., Clague, D.A., and Lockwood, J.P., 1996. Origin and depositional environment of clastic deposits in the Hilo drill hole, Hawaii. J. Geophys. Res., 101(B5):11617-11629, doi:10.1029/95JB03703.

Blichert-Toft, J., Weis, D., Maerschalk, C., Agranier, A., and Albarède, F., 2003. Hawaiian hot spot dynamics as inferred from the $\mathrm{Hf}$ and $\mathrm{Pb}$ isotope evolution of Mauna Kea volcano. Geochem. Geophys. Geosyst., 4(2): 8704, doi:10.1029/2002GC000340.

Bryce, J., DePaolo, D.J., and Lassiter, J., 2005. Geochemical structure of the Hawaiian plume: $\mathrm{Sr}, \mathrm{Nd}$ and $\mathrm{Os}$ isotopes in the 2.84 km HSDP-2 core of Mauna Kea volcano. Geochem. Geophys. Geosyst., 6: Q09G18, doi:10.1029/2004GC000809.

Büttner, G., and Huenges, E., 2002. The heat transfer in the region of the Mauna Kea (Hawaii) - constraints from borehole temperature measurements and coupled thermo-hydraulic modelling. Tectonophysics, 371:23-40, doi:10.1016/S00401951(03)00197-5.

DePaolo, D.J., and Stolper, E.M., 1996. Models of Hawaiian volcano growth and plume structure: Implications of results from the Hawaii Scientific Drilling Project. J. Geophys. Res., 101:11643-11654, doi:10.1029/96JB00070.

DePaolo, D.J., Bryce, J.G., Dodson, A., Shuster, D.L., and Kennedy, B.M., 2001a. Isotopic evolution of Mauna Loa and the chemical structure of the Hawaiian Plume. Geochem. Geophys. Geosyst., 2(7):41-43.

DePaolo, D.J., Stolper, E.M., and Thomas, D.M., 1996. The Hawaii Scientific Drilling Project: Summary of preliminary results. 
GSA Today, 6(8):1-8.

DePaolo, D.J., Stolper, E.M., and Thomas, D.M., 2001b. Deep drilling into a Hawaiian volcano. EOS, Trans. Am. Geophys. Union., 82(149):154-155.

Eisele, J., Abouchami, W., Galer, S.J.G., and Hofmann, A.W., 2003. The $320 \mathrm{kyr} \mathrm{Pb}$ isotope evolution of Mauna Kea lavas recorded in the HSDP-2 drill core. Geochem. Geophys. Geosyst., 4(5): 8710, doi:10.1029/2002GC000339.

Farnetani, C., Legras, G.B., and Tackley, P.J., 2002. Mixing and deformation in mantle plumes. Earth Planet. Sci. Lett., 196:1-15, doi:10.1016/S0012-821X(01)00597-0.

Fisk, M.R., Storrie-Lombardi, M.C., Douglas, S., Popa, R., McDonald, G., and Di Meo-Savoie, C., 2003. Evidence of biological activity in Hawaiian subsurface basalts. Geochem. Geophys. Geosyst., 5:1103, doi.10.1029/2002GC000387.

Holcomb, R.T., 1987. Eruptive history and long-term behavior of Kilauea Volcano. U.S. Geol. Surv. Prof. Pap., 1350:261-350.

Kurz, M.D., Curtice, J., Lott III, D. E., and Solow, A., 2004. Rapid helium isotopic variability in Mauna Kea shield lavas from the Hawaiian Scientific Drilling Project. Geochem. Geophys. Geosyst., 5:Q04G14, doi:10.1029/2002GC000439.

Lipman, P.W., and Moore, J.G., 1996. Mauna Loa lava accumulation rates at the Hilo drill site: Formation of lava deltas during a period of declining overall volcanic growth. J. Geophys. Res., 101(B5):11631-11641, doi:10.1029/95JB03214.

Mark, R.K., and Moore, J.G., 1987. Slopes of the Hawaiian Ridge. U.S. Geol. Surv. Prof. Pap., 1350:101-107.

Moore, J.G., 1987. Subsidence of the Hawaiian Ridge. U.S. Geol. Surv. Prof. Pap., 1350:85-100.

Moore, J.G., and Chadwick, W.W., Jr. 1995. Offshore geology of Mauna Loa and adjacent areas, Hawaii. In Rhodes, J.M., and Lockwood, J.P. (Eds.), Mauna Loa Revealed: Structure, Composition, History, and Hazards, Washington, D.C. (American Geophysical Union), 21-44.

Moore, J.G., and Clague, D.A., 1992. Volcano growth and evolution of the island of Hawaii. Geol. Soc. Amer. Bull. 104: 1471-1484, doi:10.1130/0016-7606(1992)104<1471:VGAEOT>2.3.CO;2.

Moore, J.G., Ingram, B.L., Ludwig, K.R., and Clague, D.A., 1996. Coral ages and island subsidence, Hilo drill hole. J. Geophys. Res., 101:11599-11605, doi:10.1029/95JB03215.

Morgan, W.J., 1971. Convection plumes in the lower mantle. Nature, 230:42-43, doi:10.1038/230042a0.

Novak, E.A., and Evans, S.R., 1991. Preliminary results from two scientific observation holes on the Kilauea East Rift Zone. Geotherm. Resour. Counc. Trans., 15:187-192.

Rhodes, J. M., and Vollinger, M.J., 2004. Composition of basaltic lavas sampled by phase-2 of the Hawaii Scientific Drilling Project: Geochemical stratigraphy and magma types. Geochem. Geophys. Geosyst., 5:Q03G13, doi:10.1029/2002GC000434.

Ribe, N.M., and Christensen, U.R., 1999. The dynamical origin of Hawaiian volcanism. Earth Planet. Sci. Lett., 171:517-531, doi:10.1016/S0012-821X(99)00179-X.

Robinson, J.E., and Eakins, B.W., 2006. Calculated volumes of individual shield volcanoes at the young end of the Hawaiian Ridge. J. Volc. Geotherm. Res., 151:309-317, doi:10.1016/j. jvolgeores.2005.07.033.

Sharp, W.D., and Renne, P.R., 2004. The ${ }^{40} \mathrm{Ar} /{ }^{39} \mathrm{Ar}$ dating of core recovered by the Hawaii Scientific Drilling Project (phase 2), Hilo, Hawaii. Geochem. Geophys. Geosyst., 6(4):Q04G17,
doi:10.1029/2004GC000846.

Sharp, W.D., Turrin, B.D., Renne, P.R., and Lanphere, M.A., 1996. The ${ }^{40} \mathrm{Ar} /{ }^{39} \mathrm{Ar}$ and $\mathrm{K} / \mathrm{Ar}$ dating of lavas from the Hilo 1-km core hole, Hawaii Scientific Drilling Project. J. Geophys. Res., 101:11607-11616.

Sleep, N.M., 2006. Mantle plumes from top to bottom. Earth-Sci. Rev., 77:231-271, doi:10.1016/j.earscirev.2006.03.007.

Stolper, E.M., DePaolo, D.J., and Thomas, D.M., 1996. The Hawaii Scientific Drilling Project: Introduction to the special section. J. Geophys. Res., 101:11593-11598, doi:10.1029/ 96JB00332.

Stolper, E.M., Sherman, S., Garcia, M., Baker, M., and Seaman, C., 2004. Glass in the submarine section of the HSDP2 drill core, Hilo, Hawaii. Geochem. Geophys. Geosyst., 5: Q07G15, doi:10.1029/2003GC000553.

Thomas, D.M., Paillet, F., and Conrad, M., 1996. Hydrogeology of the Hawaii Scientific Drilling Project borehole KP-1: 2. Groundwater geochemistry and regional flow patterns. J. Geophys. Res., 101:11683-11694, doi:10.1029/95JB03845.

Walton, A.W., 2008. Microtubules in basalt glass from Hawaii Scientific Drilling Project \#2 phase 1 core and Hilina slope, Hawaii: evidence of the occurrence and behavior of endolithic microorganisms. Geobiology, 6:351-364, doi:10.1111/ j.1472-4669.2008.00149.x.

Walton, A.W., and Schiffman, P., 2003. Alteration of hyaloclastites in the HSDP2 Phase 1 drill core: 1 . Description and paragenesis. Geochem. Geophys. Geosyst., 5:8709, doi.10.1029/ $2002 \mathrm{GC} 000368$.

Watts, A.B., 2001. Isostasy and Flexure of the Lithosphere. Cambridge, UK (Cambridge University Press), 458p.

\section{Authors}

Edward M. Stolper, Division of Geological and Planetary Sciences, California Institute of Technology, Pasadena, Calif., 91125, U.S.A., email: ems@caltech.edu

Donald J. DePaolo, Department of Earth and Planetary Science, University of California, Berkeley, and Earth Sciences Division, Lawrence Berkeley National Laboratory, Berkeley, Calif., 94720, U.S.A.

Donald M. Thomas, Center for Study of Active Volcanoes, University of Hawaii at Hilo, 200 West Kawili Street, Hilo, Hawaii, 96720, U.S.A.

\section{Web Links}

http://hawaii.icdp-online.org http://www.icdp-online.org/contenido/icdp/front_content. php?idcat $=714$ 